\title{
On the Relationship between the Social Intelligence and Aggression: A Case Study of High School Boy Students
}

\author{
Abbas Shekarey ${ }^{1}$, Hajar Jannesari Ladani ${ }^{2}$, Mostafa Sedaghat Rostami ${ }^{3,{ }^{*}}$ \&
} Monir Jamshidi ${ }^{2}$

${ }^{1}$ Dept. of Education, University of Kashan, Iran

${ }^{2}$ Dept. of Psychology and Counseling, Islamic Azad University, Khomeini Shahr City, Isfahan, Iran

${ }^{3}$ Dept .of English Language and Literature, Kharazmi University, Tehran, Iran

*Corresponding author: Dept .of English Language and Literature, Kharazmi University, Tehran, Iran E-mail: Mostafa_Sedaghat@yahoo.com

Received: September 13, 2012 Accepted: October 13, 2012 Published: March 16, 2013

doi:10.5296/ije.v5i1.2378 URL: http://dx.doi.org/10.5296/ije.v5i1.2378

\begin{abstract}
This study made an attempt to investigate the relationship between the social intelligence and aggression among the high school boy students in Kashan city, Iran. To conduct this study, descriptive-correlational research method was used. Descriptive method was used to describe the current status of the student's social intelligence and aggression .Correlational method was used to investigate the relationship between the social intelligence and aggression .Population of the study incorporated 3850 high school boy students of kashan city in the academic year 2010-2011. Of this population, 423 subjects were chosen through multistage cluster sampling method. To assess the subjects, measurement tools such as Buss Perry(1992) aggression questionnaire and Thout(1995) social intelligence questionnaire were used. When it came to the analysis of the obtained data, correlation coefficient and regression coefficient were used. The results showed that there was a significant relationship between the social intelligence and aggression ,especially verbal aggression, physical aggression, violence , and hostility among the high school boy students in Kashan city .The results also showed that the more students' social intelligence is, the less their aggressive behavior become .Therefore, to decrease the students' aggressive behaviors, their social intelligence should be improved through appropriate curriculum planning, and through holding in-service education programs and educational workshops for the principals.
\end{abstract}

Keywords: social intelligence; cognitive intelligence; affectionate intelligence; aggressive behaviors; physical and verbal aggression 


\section{Introduction}

Human being can achieve success by using his intelligence, that is IQ, but he may not have a great relationship with other members of the society. This kind of persons appears to be successful, but they are not aware of depriving themselves from some better successes and facilities because they have ignored or have not used usefully their social intelligence and social skills. Those whom we consider conversing and connecting with them a threat or a problematic task are more able to encourage themselves to do their works appropriately and to succeed in their works; it is possible that these persons may not have a pleasant social relation with others, and also they may have poor communicative skills .Furthermore, the environment surrounding their visible successes is a dull and lifeless environment(Bradbury \& Grifs,2008).Ethnocentric thought refers to a particular kind of thinking that make the person think only about himself and don't consider what other people need(Aronson,2004).Abstention from self-centeredness would result in some social benefits. For example, if the self-centered person abstain from self-centeredness, he will learn to respect others, to feel sympathy for some body and so on. These consequences of abstention from self-centeredness are needed in the modern society because they would cause social benefits for the society (Goleman, 1995).For many years, the most common attempts of intelligence theorists have been to incorporate the emotions in the domain of intelligence rather than considering them two opposite poles. Therefore, the known psychologist of the 1920s and 1930s Thorndike mentioned in his articles that social intelligence means the ability to understand others and to act reasonably in human relations. Thorndike(1920) also believed that intelligence is an unformed factor because we can't judge somebody's abilities by considering just his intelligence. Thorndike (1920) believed there are three kinds of intelligence: (1)social intelligence, (2)concrete intelligence , and (3) abstract intelligence. According to Thorndike's definition of social intelligence, an intelligent person is the one who has the ability to understand the others and to make a good relationship with them (Thorndike, 1936 cited in Shoja Heidari, 2009).Emotional quotient (EQ) consists of the identification and control of our own emotions. In other words, a person with high EQ combines three components of emotions including cognitive, physiological, and behavioral components(Sobhani Nejad \& Yoozbashi,2008).Goleman(1995) believed that high EQ determines why those having average IQ are more successful than those having high IQ. In the 1980s, the interest in social and affectionate intelligence was reborn by Sternberg and Gardner. Sternberg found out that when you asked a person to mention the characteristics of the intelligent persons, he would also mention the social skills as the characteristics of intelligent persons, and he would emphasize on the value of social intelligence and its difference with the academic abilities(Ciarrochi,2003). Aggressive and delinquent teenagers have mutual mental potential: when a quarrel occurs between these teenagers and another person, they will become hostile towards that person, they won't resort to peaceful solutions, and they won't picture in their minds the negative consequences of aggressive actions(Goleman,1995). Sometimes human being, especially the teenagers, resorts to the aggressive behaviors in order to secure himself from the unsafe situations(Navabi Nejad,1993).Generally speaking, there are many factors that can cause aggressive behaviors; for example, according to Akbari(2002, p.200) "frustration-aggression hypothesis can cause 
aggressive behaviors". Furthermore, Bandura(1969) believed that actions resulting in physical or financial damages should be put in the framework of aggression( Bandura 1996 cited inSadeghi,2001).Aggressive behaviors are common in the schools, and some of these aggressive behaviors reach the point that the students are expelled from the schools. These aggressive behaviors are seen more among the boys than among the girls, and it seems that the family has an effective role in forming these aggressive behaviors. According to Shekarey(2005), lack of friendly relationships, deprivation, and discrimination in the families would cause the aggressive behaviors. Furthermore, different theories are developed concerning the aggressive behaviors. For example ,Alexitimia is a psychological disorder which is the consequence of low social and affectionate intelligence. Those afflicted with Alexitimia can't feel sympathy with the others, can't understand them, and can't make a relationship with them. In a study conducted by Carol Beckenham, he showed that those afflicted with Alexitimia had much more tendency to aggressive behaviours and hostility(Mokhtaripor,2006).To cooperate, to make a good relationship ,and to feel sympathy are the social skills and lack of these skills may make the most intelligent persons in terms of cognitive intelligence feel self-centered and unsociable. However, those having middle cognitive intelligence along with high social intelligence can have a good relationship with others, feel sympathy and understand the others(Goleman,1995). Therefore, friendly relations can improve our behaviors and can be effective in evaluating the culture(White,2010:315). Aggression in different forms would have negative effects even if it is used in reacting against the students' aggressive behaviors(Shekarey,2004).Generally speaking, based on what was mentioned above, it can be said there could be a relationship between the social intelligence and aggressive behaviors. Therefore, this study aimed at investigating the relationship between the social intelligence and aggression among the high school boy students in kashan city, Iran.

\section{Research Questions}

1) Is there a relationship between the social intelligence and aggression among the high school boy students in Kashan city, Iran?

2) Is there a relationship between the social intelligence and verbal aggression among the high school boy students in Kashan city, Iran?

3) Is there a relationship between the social intelligence and physical aggression among the high school boy students in Kashan city, Iran?

4) Is there a relationship between the social intelligence and anger among the high school boy students in Kashan city, Iran?

5) Is there a relationship between the social intelligence and hostility among the high school boy students in Kashan city, Iran? 


\section{Hypothesis of the Study}

1) There is a relationship between the social intelligence and aggression among the high school boy students in Kashan city, Iran.

2) There is a relationship between the social intelligence and verbal aggression among the high school boy students in Kashan city, Iran.

3) There is a relationship between the social intelligence and physical aggression among the high school boy students in Kashan city, Iran.

4) There is a relationship between the social intelligence and anger among the high school boy students in Kashan city, Iran

5) There is a relationship between the social intelligence and hostility among the high school boy students in Kashan city, Iran.

\section{Methodology}

\subsection{Research Method}

Since the authors of this study aimed at investigating the relationship between the social intelligence and aggression, descriptive and correlational research methods were used. Descriptive method was used to describe the current status of the students' social intelligence and aggression. Then, to investigate the relationship between the social intelligence and aggressive behaviours, correlation coefficient and regression coefficient were used.

\subsection{Population and Sample}

Population of the study incorporated all high school boy students in Kashan city, Iran, in the academic year 2010-2011 which amounts to 5883 students. Since variance of the population was not clear, some members of the population were selected randomly to answer the questionnaire. Finally, after some numerical calculations, the results showed that 436 subjects should be chosen.

\subsection{Sampling method}

Subjects of the study were chosen through multistage cluster sampling method. To do so, first, 6 high schools were chosen randomly, and then in each of the selected high schools a class was chosen randomly considering the educational level of the students.

\subsection{Measurement tools}

1. Aggression questionnaire: This questionnaire was developed by Buss and Perry(1992).It is a 29-item questionnaire and for each item 5 point scale are provided. If a person circles number 5, it means that he is very aggressive. In this questionnaire four aspects of aggression(verbal aggression, physical aggression, anger , and hostility) are measured. According to the developers of the questionnaire, validity and reliability of the questionnaire are $\% 86$ and $\% 82$ respectively. In this study, after a follow-up study was conducted, and 
variance of the questions was determined, reliability of the questionnaire was measured by Cronbach's alpha; it amounts to $\% 86$.

2. Social intelligence questionnaire: This questionnaire is developed by Thout (1995). This is a 45-item questionnaire and there are two options for each item: correct and incorrect. According to the developers of the questionnaire, validity and reliability of the questionnaire are $\% 82$ and $\% 85$ respectively.In this study, after a follow-up study was conducted and variance of the questions was determined, reliability of the questionnaire was measured by Cronbach's alpha; it amounts to $\% 84$.

\subsection{Data Analysis}

In this study, descriptive statistics such as frequency, percent, mean, and standard deviation were used. To analyze the data, referential statistics such as correlation coefficient and regression coefficient were used.

\section{Results of the Study}

$1^{\text {st }}$ hypothesis: There is a relationship between the students' social intelligence and aggression in Kashan, Iran.

Table 1: Results of Pearson correlation coefficient between the social intelligence and aggression

\begin{tabular}{llll}
\hline Variables & Frequency & $\begin{array}{l}\text { Correlation } \\
\text { coefficient(r) }\end{array}$ & Level of significance \\
\hline Social intelligence and aggression & 423 & -0.56 & 0.001 \\
\hline
\end{tabular}

Table 1 showed that there was a negative significant relationship between the students' social intelligence and aggression. In other words, if the student has a high social intelligence, he will show less aggressive behaviors. Therefore, the first hypothesis of the study is supported.

$2^{\text {nd }}$ hypothesis: There is a relationship between the students' social intelligence and verbal aggression.

Table 2: Results of Pearson correlation coefficient between the social intelligence and verbal aggression

\begin{tabular}{llll}
\hline variables & Frequency & $\begin{array}{l}\text { Correlation } \\
\text { Coefficient(r) }\end{array}$ & Level of significance \\
\hline $\begin{array}{l}\text { Social intelligence and verbal } \\
\text { aggression }\end{array}$ & 423 & -0.52 & 0.001 \\
\hline
\end{tabular}

Table 2 showed that there was a negative significant relationship between the students' social intelligence and verbal aggression. In other words, if the student has a high social intelligence, he will show less verbal aggression. Therefore, the second hypothesis of the study is 
supported.

$3^{\text {rd }}$ hypothesis: There is a relationship between the students' social intelligence and physical aggression.

Table 3: Results of Pearson correlation coefficient between the social intelligence and physical aggression

\begin{tabular}{llll}
\hline variables & Frequency & $\begin{array}{l}\text { Correlation } \\
\text { coefficient(r) }\end{array}$ & Level of significance \\
\hline $\begin{array}{l}\text { Social intelligence and } \\
\text { physical aggression }\end{array}$ & 423 & -0.59 & 0.001 \\
\hline
\end{tabular}

Table 3 showed that there was a negative significant relationship between the students' social intelligence and physical aggression. In other words, if the student has a high social intelligence, he will show less physical aggression. Therefore, the third hypothesis of the study is supported.

$4^{\text {th }}$ hypothesis: There is a relationship between the students' social intelligence and anger

Table 4: Results of Pearson correlation coefficient between the social intelligence and anger

\begin{tabular}{llll}
\hline variables & Frequency & $\begin{array}{l}\text { Correlation } \\
\text { Coefficient(r) }\end{array}$ & Level of significance \\
\hline Social intelligence and Anger & 423 & -0.62 & 0.001 \\
\hline
\end{tabular}

Table 4 showed that there was a negative significant relationship between the students' social intelligence and anger .In other words, if the student has a high social intelligence, he will show less anger. Therefore, the fourth hypothesis of the study is supported.

$5^{\text {th }}$ hypothesis: There is a relationship between the students' social intelligence and hostility.

Table 5: Results of Pearson correlation coefficient between the social intelligence and hostility

\begin{tabular}{llll}
\hline Variables & Frequency & $\begin{array}{l}\text { Correlation } \\
\text { coefficient(r) }\end{array}$ & Level of significance \\
\hline $\begin{array}{l}\text { Social intelligence and } \\
\text { hostility }\end{array}$ & 423 & -0.46 & 0.001 \\
\hline
\end{tabular}

Table 5 showed that there was a negative significant relationship between the students' social intelligence and hostility .In other words, if the student has a high social intelligence, he will show less hostility. Therefore, the fifth hypothesis of the study is supported. 
Table 6: Results of the regression coefficient of the effect of Social intelligence on aggression

\begin{tabular}{llllll}
\hline Variables & $\begin{array}{c}\text { Error } \\
\text { level }\end{array}$ & $\begin{array}{l}\text { Regression } \\
\text { Coefficient }\end{array}$ & t-observed & t-critical & $\begin{array}{c}\text { Level } \\
\text { significance }\end{array}$ \\
\hline Aggression & $0 / 04$ & $-0 / 80$ & $1 / 14$ & $0 / 62$ & $0 / 001$ \\
$\begin{array}{l}\text { Physical } \\
\text { Aggression }\end{array}$ & $0 / 05$ & $0 / 81$ & $1 / 16$ & $0 / 62$ & $0 / 001$ \\
$\begin{array}{l}\text { Verbal Aggression } \\
\text { Anger }\end{array}$ & $0 / 03$ & $0 / 71$ & $1 / 02$ & $0 / 62$ & $0 / 001$ \\
Hostility & $0 / 01$ & $0 / 89$ & $1 / 35$ & $0 / 62$ & $0 / 001$ \\
\hline
\end{tabular}

Furthermore, table 6 showed that social intelligence can have an effect on the components of aggression. Therefore, if the student has a high social intelligence, he will show less aggressive behaviours.

\section{Discussion and Conclusion}

The results of the study showed that there was a negative and significant relationship between the students' social intelligence and their aggressive behaviors. In other words, the students having high social intelligence are calm and they indicate less aggressive behaviors. As the results of the study indicated, there was a negative significant relationship between the students' social intelligence and aggression; this result corresponds to the results of the study conducted by Dibo \& Pirnis(2006). Concerning the second result of study, that is there was a negative significant relationship between the students' social intelligence and verbal aggression, we can name the results of another study conducted by Bazargan and et al.(2004) that corresponds to the second result of our study. The third result of the study, that is there was a negative significant relationship between the student's social intelligence and physical aggression somehow completed the results of the study conducted by Ka'fai and et al.(2009). The fourth result of the study, that is there was a negative significant relationship between the students social intelligence and anger is consistent with the results of the study done by Sadeghi and et al.(2002).Finally, the fifth result of our study, that is there was a negative significant relationship between the students' social intelligence and hostility is confirmed by the results of the study conducted by Cohen (1976) and Berkowitz(1973). The results also show that the more students' social intelligence is, the less their aggressive behaviors become. Therefore, to decrease the students' aggressive behaviors, heir social intelligence should be improved. Of the measures that can improve the social intelligence, appropriate curriculum planning, holding in-service education programs, and educational 
workshops for the principals can be mentioned. Furthermore, there are many methods to control and to prevent the aggressive behaviors; this study emphasizes on the educational and psychological methods including improving a pleasant relationship between the parents and children, training how to control oneself, changing cognitive constructs, and preventing the children from watching aggressive movies.

\section{References}

Akbari, A. (2002). Problems of the Teenagers and Youth. Tehran: Savan Press.

Aronson. E. (2004). Social Psychology. Translated by Shekarkan. Tehran: Roshd Press.

Bandura, A. (1986). Social Foundations of Thought and Action. Engelwood Cliffs, NJ: Prentice-Hall.

Berkowitz, L. (1973). "control of aggression". In B. Caldwell \& H . Ricciuti (Eds), Review of child development research, vol. 111 . Chicago: University of Chicago press.

Bradbury. T., \& Grifs. J. (2008). What is EQ and why the level of IQ is important. Translated by Ebrahimi. Tehran: Nasl Noandish Press

Ciarrochi, J. (2003). Emotional Intelligence in Every dey Life. USA, Psychology press, 1st, p.21.

Cohen, S. (1976). Social and Personality development in childhood. New York: Macmillan.

Goleman, D. (1995). 'Emotional Intelligence why It can Matter More Than IQ. UK, Bloombsbury, 1st, p42.

MokhtariPor, M. (2006). Emotional Intelligence and its Disorders. Isfahan: Research week conference.

Navabinejad, SH. (1993). Aberrant and Usual Behaviors of the Children: Prevention and treatment. Tehran: Iranian association of parents and educators Press.

Sadeghi, A. (2001). The Effect of Controlling Anger on the Reduction of the Students' Aggressive Behaviors. Thesis. Isfahan University.

Shekarey, A. (2004). Educational Issues in Iran and Solutions. Tehran: Abed Press.

Shekarey, A. (2005). Agression and its Treatment. Tehran: Iranian association of parents and educators Press.

Shoja Heydari, M. (2009). A Study on the Relation of Emotional Intelligence on the Students' Academic Performance. Thesis. Isfahan University.

Sobhanineja, M., \& Yoozbashi. A. (2008). Emotional Intelligence in the Management of Organizations. Tehran: Yastaroon Press.

Thorndike, E.L. (1920). Intelligence and its use. Harper's Magazine, 140, 227-235. 
Thorndike, R.L. (1936). Factor analysis of social and abstract intelligence. Journal of Educational Psychology, 27, 231-233. http://dx.doi.org/10.1037/h0059840

White. David J. (2010). The Form and Function of Social Development: Insights From a Parasite . Current Directions in Psychological Science, October 2010; vol. 19, 5: pp. 314-318., first published on October 4, 2010 $\mathrm{http}: / /$ cdp.sagepub.com/search?fulltext=social interaction \& sortspec $=$ date \&submit=Submit \& andorexactfullt. 3Nov 2010.

\section{Copyright Disclaimer}

Copyright reserved by the author(s).

This article is an open-access article distributed under the terms and conditions of the Creative Commons Attribution license (http://creativecommons.org/licenses/by/3.0/). 